\title{
JAPANSKI MITOVI O STVARANJU
}

Mitovi o stvaranju sveta ili određene zajednice, mogu se sastojati od različitih narativnih oblika i poetskih slika, što je uslovljeno fundamentalnim aspektima života u drevnoj zajednici, religijskim simbolima, društvenim normama i običajima itd, koji konstituišu određenu tradiciju. Takvi mitovi u Japanu zabeleženi su u dva najstarija sačuvana pisana spomenika: Kođiki (Zapisi o drevnim događajima, 712) i Nihongi (Zapisi o Japanu, 720). Iako su ova dva dela slična po formi i sadržaju, njihove funkcije su različite. Kođiki je istorijski zapis, nastao s ciljem da izrazi mitološku viziju porekla carske porodice i istorije carevine. Upravo zato insistira na jednoj zvaničnoj varijanti priče - onoj koja je najviše odgovarala carskoj vlasti. S druge strane, Nihongi je prva službena istorija Japana, kojom se dokazivala autonomnost japanske carevine u odnosu na Kinu i Koreju. Nihongi ističe bogatstvo lokalnih kultura tako što čuva sve dostupne varijante mitova i legendi. Razlike između ova dva dela vidljive su već na samom početku, u mitovima o postanku sveta. Nihongi daje više varijanti ovog mita. Dok u prvoj prepoznajemo odraze kineske mitologije i filozofije, ostale varijante iz Nihongija, kao i ona odabrana za Kođiki, oslikavaju šintoističke predstave o stvaranju sveta. Za japansku mitologiju je karakteristično izjednačavanje teogonija s kosmogonijama, ali i etiološkim mitovima, budući da nastanak božanskog duha istovremeno označava poreklo različitih elemenata pojavnog sveta, kao i imaginarnih pojmova. Proces stvaranja vrši se na različite načine: polnim sjedinjenjem prapredačkog para, transformacijom izlučevina boginje, krvi i delova tela ubijenog božanstva, obrednim pročišćenjem, partenogenezom itd.

Ključne reči: Kođiki, Nihongi, šinto, japanska mitologija, mitovi o stvaranju, kami, teogonije, kosmogonije

Oduvek je u ljudskoj svesti sazrevala misao o postanku vremena, prostora i materije. To je nešto što je zajedničko svim narodima, tako da gde god da krenemo, nailazimo na mitove o stvaranju sveta ili zajednice iz koje su potekli. Ti mitovi mogu se sastojati od različitih narativnih oblika i

* vasic.danijela@fil.bg.ac.rs 
poetskih slika, što je uslovljeno fundamentalnim aspektima života u drevnoj zajednici, religijskim simbolima, društvenim normama i običajima koji konstituišu određenu tradiciju. Brojni istraživači došli su do zaključka da se takve pripovesti ipak ne razlikuju u tolikoj meri, kako bi se na prvi pogled moglo zaključiti. Različite verzije variraju u detaljima, ali je njihova osnova uvek srodna ili barem dele zajedničke elemente. Sličnost mitskih predstava i ideja kod udaljenih kultura godinama intrigira naučnike.

Jedan od vodećih proučavalaca mita o stvaranju, Rejmond Van Over, zaključuje sledeće: „Iznenađujuća je i zbunjujuća činjenica da su ovi mitovi u naširoko različitim geografskim područjima zapanjujuće slični u pogledu svojih osnovnih tema." (1980: 10)

Čovečanstvo je oduvek volelo priče, a većina drevnih mitova i jesu priče u koje su nekada ljudi, manje ili više verovali. I Kembel (2004: 256) primećuje da su oblikovanje sveta ili stvaranje čoveka teme tipične za priče o prvobitnom stvoritelju. Ipak, teško je proceniti koliko su one ozbiljno shvatane, ali je verovatnije da su na njih gledali kao na narodne bajke, nego na knjigu postanja. Ako su ih neobrazovaniji članovi zajednice i primali s neprimerenom ozbiljnošću, u celini se za njih ne može reći da predstavljaju religijsko učenje. Kembel zaključuje da je ovako „razigrano mitologiziranje zajedničko svim civilizacijama, i višim i nižim" (Kembel, 2004: 256).

Hari Elis o tome piše sledeće: „Ako je neko upoznat sa prirodom mita (čak i na elementarnom nivou), onda mora biti svestan da se još drevni narodi, koji su ih i stvarali, nisu obavezno slagali sa njihovom 'literarnom' interpretacijom. Verovalo se da je istiniti sadržaj mita veći, i to u moralnom ili religijskom smislu, nego što je to jednostavno opis fizičke stvarnosti.“ (Ellis, 1982: 12). Tako se i mitovi o postanju samo uzgredno odnose na stvaranje. Njihov primarni cilj je da se bave problemima života, poput Epa o Gilgamešu. Drugim rečima, mnoge priče o stvaranju nisu ni nastale sa ciljem da informišu o tome kako je svet bio stvoren, već kako bi nas poučile nekim moralnim principima ili određenim elementima tradicije (up. Hasel, 1974). Mi se u našem radu ipak nećemo baviti time kako su stari narodi prihvatali ove mitove, već ćemo se zadržati na samom sadržaju mita o stvaranju, prevashodno u japanskoj kulturi.

Mit o stvaranju je pripovest koja opisuje način na koji je, najčešće iz prvobitnog haosa, nastao kosmos i kako je on prvobitno izgledao. ${ }^{1}$ To mit o stvaranju izjednačuje sa kosmogonijom. U nekim kulturama, poput ja-

$1 \quad$ O mitovima o stvaranju v: Long, 1963. 
panske, kosmogonija se može poistovetiti i sa teogonijom zato što upravo postanak prvobitnih božanstava simbolizuje nastanak elemenata od kojih je sačinjen pojavni svet. ${ }^{2}$ Sadašnje stanje pojavnog sveta: izgled reljefa, nebeska tela, životinjske i biljne vrste, ali i ,način života, socijalne grupacije i religiozne konstatacije, svi prirodni i kulturni objekti“ i mnogo toga drugog, posledica su radnji mitskih junaka i bogova u mitsko (pra)vreme. (Meletinski, 2009: 31-32).

Takvi mitovi u japanskoj tradiciji zabeleženi su u dva najstarija sačuvana pisana spomenika u Japanu: Kođiki (Zapisi o drevnim događajima, $712)^{3}$ i Nihongi (ili Nihonšoki, Zapisi o Japanu, 720). ${ }^{4}$ Forma i sadržaj oba dela su slični, pre svega zato što počivaju na drevnoj politeističkoj religiji iz koje su ponikla. To je ogroman kompleks verovanja, običaja i institucija, koji je dobio naziv šinto (put bogova), kako bi se razlikovao od religija donetih iz Kine, budizma i konfucijanizma. Šinto je animistička religija, koja podrazumeva da svaki element od kog je načinjen ovaj svet u sebi nosi svoju duhovnu prirodu, boga ili duha (na japanskom: kami - bog). Ovi bogovi-duhovi, svojim imenima su povezani sa prirodnim pojavama koje predstavljaju. Ima ih osam miliona, ${ }^{5}$ i među njima ćemo pronaći i antropomorne likove fantastičnih svojstava: prapretke i kulturne junake, kao i junake sa negativnim osobinama - trikstere, kojima je svojstveno da naizmenično stvaraju i dezorganizuju svet.

Ono, pak, što naročito razlikuje Kođiki i Nihongi, jesu ciljevi njihovog nastanka. Kođiki je najstarije književno delo koje danas postoji u Japanu. Napisano je sa ciljem da se narodu ukaže na legitimnost carske porodice. Naredbu o njegovom sastavljanju izdao je car Tenmu (vl. od 673-686), koji je preuzeo vlast 672 . godine. U cilju učvršćivanja centralističke vlasti, car

2 O tome detaljno piše Acuhiko Jošida, koji izvodi zaključke poredeći japanske mitove s grčkim mitovima (up. Yoshida, 1966; 1974).

3 Za kompletan prevod dela sa starojapanskog na srpski jezik v. Kođiki - Zapisi o drevnim događajima, a za japansku verziju v. Ogihara, 1973, odakle su preuzeti citirani delovi.

4 Za prevod dela na engleski jezik v: William, G. A. (ed., transl.), 2005; za japansku verziju v: Sakamoto, 1982, odakle su preuzeti i prevedeni citirani delovi.

Povoda za polemiku davalo je postojanje još jednog dela - Kuđiki (Zapisi o događajima iz starina). Naime, dok jedni veruju da je reč o još starijem istorijskom zapisu, nastalom oko 620. godine, drugi, na osnovu ranijih hronika, dokazuju da je napisano kasnije.

5 Osam je sveti broj u japanskoj mitologiji i označava mnoštvo: „osam miliona“ znači „bezbroj“. 
donosi odluku da se od carskih rodoslova, (Teiki - Hronika careva), kao i od usmene tradicije, sabrane u Knjigama predanja (Kjuđi), sačini jedinstven zapis kojim bi mogao opravdati svoje božansko poreklo. Posle careve smrti, carica Genmei (vl. od 707-715) naređuje dvorskom naučniku po imenu Oo no Jasumaro (?-723) da dovrši poduhvat. Jasumaro je rukopis predao dvoru 712. godine. Kođiki se sastoji od tri toma, koji pokrivaju vreme od nastanka sveta i osnivanja Japana, pa sve do vladavine carice Suiko, početkom VII veka. Ovaj zapis je važan jer je sačuvao običaje, jezik, tradicionalnu istoriju, mitologiju i verovanja drevnih Japanaca, a pre svega stoga što tim delom započinje japanska pisana književnost. Iako je reč o proznom delu, Kođiki poseduje i osobine usmene književnosti, ritmičan je i melodičan, sa ponavljanjima svojstvenim usmenim formama. U njemu preovlađuju priče s mnoštvom mitoloških i čudesnih elemenata, kao što su: kosmogonija, teogonija, etiološka i mitološka predanja, etnološki zapisi i legende o poreklu članova carske porodice i vodećih klanova, kao i etimologije toponima itd.

Osam godina nakon sastavljanja Kođikija, 720. godine nastaje i drugi istorijski zapis u Japanu, Nihongi. To je knjiga na klasičnom kineskom jeziku (kanbun), napisana po uzoru na zvanične istorije kineskih dinastija. Priređivač je princ Toneri, a u priređivanju je učestvovao i priređivač Kođikija, Oo no Jasumaro. Nihongi je zapis koji naglašava nacionalni identitet Japanaca i dokazuje autonomnost carevine u odnosu na Kinu i Koreju. Ovo potvrđuje i činjenica da ovo delo u većoj meri sadrži istorijske činjenice i teži faktografskom prikazivanju vremena.

Takođe, Nihongi pokazuje različitost lokalnih kultura jer čuva sve varijante mitova i legendi, što upravo govori o rasprostranjenosti različitih tema i motiva, dok istovremeno pruža dokaze o stranim uticajima na japansku kulturu. Kođiki je, naprotiv, namenjen samim Japancima. Nastao je s ciljem da izrazi mitološku viziju porekla carske porodice i istorije carevine, tako da insistira na jednoj zvaničnoj varijanti priče, upravo onoj koja je najviše odgovarala carskoj vlasti. Ove razlike vidljive su već na samom početku oba dela, u mitu o postanju. Varijanta odabrana za Kođiki, kao i sve verzije ovog mita iz Nihongija, osim prve, oslikavaju šintoističke predstave o postanku sveta.

Oba dela počinju kosmogonijskim i teogonijskim procesima, pre svega razdvajanjem neba i zemlje, da bi, zatim, svaki dalji korak u evoluciji univerzuma simbolizovao kami odgovarajućeg imena. U Kođikiju (18-19 str.) piše: 
„Kada se na početku razdvojiše Nebo i Zemlja, na Uzvišenom nebeskom polju nastade bog Ame no Minakanuši [Nebeski bog Središnji gospodar], zatim bog Takami Musuhi [Uzvišeni bog Stvoritelj], a zatim bog Kamu Musuhi [Sveti bog Stvoritelj]. Sva tri nastadoše kao samotni bogovi i nikad se ne ukazaše. I dok zemlja u začetku plutaše kao masnoća na površini vode, nošena poput meduze, nastade bog po imenu Umaši Ašikabi Hikođi [Predivni stari bog trskovog izdanka] kao što izdanak trske niče, a zatim bog Ame no Tokotaći [Bog večnosti Neba]. I ova dva božanstva nastadoše kao samotni bogovi i nikad se ne ukazaše. Ovih pet božanstava jesu posebni nebeski bogovi. Potom nastade bog po imenu Kuni no Tokotaći [Bog večnosti Zemlje], a zatim bog Tojo Kumono [Bog bujnog polja oblaka]. I ova dva božanstva nastadoše kao samotni bogovi i nikad se ne ukazaše."

Diferencijacija neba i zemlje jedan je od prvih koraka u pretvaranju haosa u kosmos, što ujedno čini osnovni smisao mitologije. Haos je personifikacija praiskonske praznine, koja prethodi stvaranju i vremenu u kome nije vladao red među elementima sveta (up. Ševalije, Gerbran, 2004: 261-262). Izdvajaju se, dakle, dve sfere - nebeska i zemaljska, da bi se kasnije uvela i treća, podzemna, i tako nastaju elementi koje Meletinski naziva „,normalnom trihotomijskom strukturalnom shemom kosmosa“ (1984: 234).

Odmah po razdvajanju neba i zemlje, na Uzvišenom nebeskom polju nastaju prvi nebeski bogovi-stvoritelji. Ovo nije odlika samo japanske tradicije, jer se nastanak univerzuma u mitologijama često izjednačava sa teogonijom. Pri tom se na teogonijsku strukturu u Kođikiju može primeniti zaključak Meletinskog da se u razvijenim mitologijama iznad prapredaka - demijurga i kulturnih junaka uzdižu ,panteoni bogova (u čijem su nastajanju učestvovali i preci i duhovi - gospodari), koji su, po pravilu, lokalizovani na nebu i modeluju najrazličnije prirodne predmete i pojave i razne socijalne funkcije“ (Isto: 196). Prelaz od prapredaka, koji su u strogoj korelaciji sa mitskim vremenom, ka bogovima koji upravljaju svetom veoma je suštastven vid prelaska od arhaične mitologije ka razvijenijim formama.

Početni segment veoma dobro ilustruje osnovnu karakteristiku japanskog zapisa, koji je nastao kako bi se podržalo ujedinjenje nacije pod centralnom upravom. Mitologiju predstavljenu u Kođikiju čini unija tri 
velika mitološka sistema (up. Obayashi, 1961: 78). Prvi je negovan u plemenskom savezu oko osnivača dvora u zemlji Jamato. To su mitovi o nebeskim bogovima na Uzvišenom nebeskom polju, kojima vlada Velika boginja sunca, Amaterasu. Karakteriše ih koncept nebeske vlasti i obredi vezani za poljoprivredu. Drugi sistem čini svet zemaljskih bogova, zapravo careva koji su predstavljeni kao bogovi na zemlji. Njih su poštovali vladari zemlje Izumo, a svojstven im je razvijen kult boga gromovnika Take Haja Susanoa. Pored toga, ističu se i predstave o božanstvima voda, kao i kult vrhovnog boga stvaraoca zemlje, Ookuninušija. Treći mitološki sistem potiče sa ostrva Kjušu i sastavljen je od brojnih verovanja koja se mogu pripisati primorskim plemenima. Određene nedoslednosti u mitovima iz Kođikija jasan su odraz postojanja ovih različitih izvora.

U tom smislu, vrhovni bog Ame no Minakanuši, kako se smatra, naknadno je uveden da bi ujedinio mitološke sisteme Jamato i Izumo. Sledeći, Takami Musuhi, vrhovni je bog mitološkog sistema Jamato, dok je bog Kamu Musuhi - vrhovni bog mitološkog sistema Izumo. Poetska slika prvobitne zemlje što pluta kao masnoća na površini vode, nošena poput meduze, pokazuje uticaj trećeg mitološkog sistema koji se pripisuje primorskom narodu Ama. Isto tako, kao posledica stapanja više mitoloških sistema, u imenu boga Umaši Ašikabi Hikođija, javlja se oznaka za muškarca, hiko, uprkos činjenici da polovi još uvek nisu bili razdvojeni.

U verziji mita o postanju, prikazanoj u Kođikiju, prvih sedam bogova nastaje spontano, a njihovom aktivnošću započinje stvaranje. Osim toga, bog večnosti Neba, Ame no Tokotaći, koncipiran je da bi se pokazalo kako je Nebo konačno uobličeno posle aktivnosti bogova Stvoritelja, dok od boga večnosti zemlje, Kuni no Tokotaćija, počinje proces ustaljenja Zemlje. Ovi bogovi simbolišu evoluciju univerzuma, čime su svoju funkciju obavili, da bi potom nestali. ${ }^{6}$ Oni su usamljeni (samotni), što znači da nemaju svog para suprotnog pola jer polovi još uvek nisu bili razdvojeni. Samim tim, oni ne mogu da budu nosioci daljeg stvaranja, za šta je potreban spoj muško-ženskog principa.

U drugom istorijskom zapisu, Nihongiju, sve verzije mita o postanju, osim prve, zapravo su varijante inicijalnog dela Kođikija. To je u tekstu stilizovano formulom „u jednom tekstu se kaže“, koja se ponavlja:

6 Iako nestaju, ovi bogovi nastavljaju da postoje u nebeskoj sferi. U prilog tome govori i to što se neki od njih, npr. bogovi Takami Musuhi i Kamu Musuhi kasnije javljaju kao donosioci odluka, zajedno sa vrhovnom boginjom Amaterasu. 
U jednom tekstu se kaže: kad Nebo i Zemlja nastadoše, nešto se pojavi usred praznine. Obličje mu se ne mogaše opisati. U tome, samoniklo, nastade bog kome ime beše Kuni Tokotaći, a koji se naziva i bog Kuni Sokotaći. Za njim nastade bog Kuni Sacući, koji se naziva i bog Kuni Sataći. Za njim nastade bog Tojo Kuninuši, koji se naziva i bog Tojo Kumunu, bog Tojo Kafuši, bog Ukifu no Tojokahi, bog Tojo Kuni, bog Tojo Kuhi, bog Hako Kuni i bog Mino.

U jednom tekstu se kaže: u starini, kad kopno beše mlado, a zemlja mlada plivaše unaokolo kao masnoća što pluta. Tada se nešto načini unutar kopna, u obličju nalik izdanku trske. Od toga nastade bog čije ime beše Umaši Ašikabi Hikođi. Za njim nastade bog Kuni no Tokotaći, a za njim bog Kuni no Sacući.

U jednom tekstu se kaže: kad Nebo i Zemlja behu u stanju haosa, nastade prvi od svih bogova, čije ime beše Umaši Ašikabi Hikođi. Za njim nastade bog Kuni no Sokotaći.

U jednom tekstu se kaže: kad Nebo i Zemlja nastadoše, behu bogovi što postaše zajedno, a imena im behu, prvo bog Kuni no Tokotaći, a zatim bog Kuni no Sacući. Dalje se kaže: Imena bogova što načiniše Uzvišeno nebesko polje, behu bog Ama no Minakuniši, zatim bog Takami musubi i zatim bog Kami Musubi.

U jednom tekstu se kaže: pre nego što postaše Nebo i Zemlja, beše nešto što se može porediti sa oblakom koji pluta po moru. Ne beše mesta za koji bi se mogao vezati njegov koren. Usred toga stvori se nešto nalik izdanku trske kad nikne iz blata. To nešto odmah se pretvori u ljudsko obličje po imenu bog Kuni no Tokotaći.

U jednom tekstu se kaže: kad Nebo i Zemlja nastadoše, nešto što beše nalik izdanku trske, beše stvoreno usred praznine. To nešto pretvori se u boga po imenu Ama no Tokotaći, a za njim u boga Umaši Ašikabi Hikođija. Dalje se kaže: nešto nastade usred praznine nalik masnoći što pluta, od čega postade bog po imenu Kuni Tokotaći.

$\mathrm{U}$ ovim varijantama smenjuju se uglavnom isti bogovi stvoritelji, uz variranje ostalih elemenata. Većinu njih vezuje motiv trske, što je osobenost japanske tradicije. Trska raste i do $15 \mathrm{~cm}$ na dan, i njena životna snaga obožavana je kao simbol plodnosti zemlje. Uz to, zemljište obraslo 
trskom je dobro navodnjeno, pa samim tim pogodno za gajenje pirinča osnovne žitarice u ishrani Japanaca. Upravo iz tog razloga se središnja sfera, koja se nalazi u sredini između Uzvišenog nebeskog polja i podzemne Zemlje noćne tame, naziva Središnja zemlja trščanih polja. U varijantama mita o postanju iz Nihongija možda je najzanimljivija pretposlednja, koja sugeriše postanak, ,ljudskog obličja“, budući da je to jedino mesto u japanskoj mitologiji koje govori o postanku čoveka.

S namerom smo preskočili prvu verziju mita o postanju iz Nihongija, jer u poređenju s ostalim, pokazuje posebne karakteristike:

U starini, Nebo i Zemlja još uvek ne behu razdvojeni, a Jin i Jang još uvek ne behu odeljeni. Načini se haotična materija nalik jajetu bez jasno određenih granica, što sadržavaše klice. Čistiji i jasniji deo beše malo izvučen, te se od njega načini Nebo, dok se teži i grublji deo nataloži, pa od njega postade Zemlja. Od tog finijeg elementa lakše postade jedno telo, dok se onaj teži i grublji ostvari uz poteškoće. Nebo, dakle, beše prvo stvoreno, a Zemlja beše naknadno uspostavljena. Nakon toga između njih nastadoše božanska bića. Stoga se kaže da kad svet poče da se stvara, zemlja od koje kopno beše uspostavljeno plutaše unaokolo, na način koji se može porediti sa plutanjem ribe što se ukazuje na površini vode. U to vreme nešto se načini između Neba i Zemlje. Beše u obličju izdanka trske. Onda se to pretvori u boga i nazva se imenom bog Kuni Tokotaći. Za njim nastade bog Kuni no Sacući, a za njim bog Tojo Kumunu. Sveukupno tri boga. Svi oni behu muški što se spontano razviše delanjem nebeskih načela.

Mnogi naučnici, među kojima i Meletinski, primećuju da se postanak kosmosa često prikazuje kao nastanak iz jajeta (up. Meletinski, 1984: 204). I Kembel ističe da je ,slika kosmičkog jajeta poznata u mnogim mitologijama; javlja se u grčkoj orfičkoj, egipatskoj, finskoj, budističkoj i japanskoj“ (Kembel, 2004: 245). U varijanti mita iz Nihongija prepoznajemo odraze kineske mitologije i filozofije, i to, pre svega, u prvobitnom haosu koji ima oblik jajeta i u isticanju muškog i ženskog principa (Jin i Jang). Jasno je da ovaj početak nema zajedničkih elemenata sa japanskom tradicijom. Štaviše, osnivač škole Kokugaku, Motoori Norinaga, ${ }^{7}$ ukazuje

$7 \quad$ Sledbenici škole Kokugaku (u prevodu: Nauka o Japanu) nastojali su da izučavanjem dugo zanemarenih drevnih književnih tekstova otkriju izvorni duh Japana iz perio- 
na neprirodnost veznika „stoga“ na početku središnje rečenice u tekstu, sugerišući da je njegova jedina funkcija da poveže kinesku pripovest sa japanskom koja sledi. Prisutnost ovog segmenta jasno govori o funkciji Nihongija, namenjenog predstavljanju Japana pred (velikom) Kinom.

Zanimljivo je pogledati uvodni tekst Kođikija (9. str.), koji je napisao pređivač dela, Oo no Jasumaro, i gde on upoznaje čitaoce sa sadržinom dela, obrazlaže razloge nastanka i metode korišćene pri pisanju. Uvod počinje sledećim rečima:

„Ja, podanik Jasumaro, pokorno izveštavam:

Nekada davno, haos koji beše ishodište stade da se zgušnjava, a još mu se ni duh ne pokaza. Ne beše mu ni imena, ni dela. Ko bi znao njegovo obličje? No, onda se razdvojiše Nebo i Zemlja, i tri boga behu početak stvaranja, pojaviše se Jin i Jang, dva Duha postaše praroditelji svega postojećeg. Pošto On ode u tamu i vrati se na svetlost dana, sunce i mesec nastaše pri omivanju očiju Njegovih, a dok je tonuo u more i iz njega izranjao, bogovi se pojaviše pri ispiranju tela Njegovog."

Srodnom postupku, kao što vidimo, pribegli su priređivači oba dela. Jasumaro, doduše, verziju iz kineskih hronika nije stavio u sam tekst Kođikija, ali nije izbegao da dualistički koncept Jin-Jang poistoveti sa praroditeljima, bogovima Izanakijem i Izanami. U daljem tekstu Uvoda, nailazimo i na rečenicu kojom Jasumaro opisuje jednog od japanskih careva: „Vođen skladnim delanjem dva duha [opet Jin i Jang], i urednim kruženjem pet kosmičkih činilaca [drvo, vatra, zemlja, metal i voda], ustanovi načela po kojima se poštuju bogovi, čime se podsticaše dobri običaji, te pronese krasne vrline, čime se zemlja proširi.

Kođiki i Nihongi dalje nastavljaju u istom duhu: Kođiki sa samo jednom odabranom verzijom mita, a Nihongi sa svim dostupnim varijantama mitoloških priča, uz provejavanje uticaja kineske filozofije. Mi ćemo se zadržati na građi iz Kođikija.

Posle samotnih bogova nastaju četiri muško-ženska para: bog blata Uhiđini i boginja peska Suhiđini oličavaju stvaranje tla; bog bokorenja bil-

da pre dolaska budizma i konfucijanizma. Jedan od tih sledbenika bio je i Motoori Norinaga (1730-1801). Njegovo obimno naučno delo Kođikiden (O delu Kođiki, 1764-1798) i danas je temelj istraživanja ovoga zapisa i vrhunac japanoloških studija modernog doba. Norinaga je isticao da Kođiki sadrži najčistiji zapis starog japanskog jezika i verovao je da se čitanjem ovoga dela mogu rasvetliti istorijski događaji drevnog Japana. 
ja Cunogui i boginja rađanja bilja Ikugui simbolizuju nastajanje flore; bog velikih vrata Otonođi i boginja velikih vrata ${ }^{8}$ Otonobe označavaju nastajanje faune. Za njima nastaju: bog usavršavanja zemlje Omodaru, kojim je stvaranje zemlje završeno, i boginja velikog poštovanja Ajašikone, kojom se izražava divljenje prema ostvarenom delu.

Pojava božanskih parova podrazumeva rođenje antropomorfnih bića, ali istovremeno oličava i nastanak elemenata žive, nežive prirode i civilizacijskih pojava. To znači da su kroz pojavu nebeskih bogova kamija, drevni Japanci videli njihovu materijalizaciju. Ceo svet, prirodu i društvo u raznim vidovima oličava i njima upravlja ukupnost ovih bogova. Iz toga proizilazi da japanski panteon čini zbir personifikovanih prirodnih, geografskih i drugih pojava, na koju nam ukazuje ime novonastalog kamija. Drugim rečima, teogonija u japanskoj mitologiji može istovremeno imati i kosmogonijsku ili etiološku funkciju. Često je ta granica nejasna i funkcije nije moguće striktno kategorisati.

Ova pojava nije prisutna isključivo u japanskoj mitologiji. Meletinski ističe da se postanak sveta u mitologijama često prikazuje kao „lanac teogonija koje modeluju određene fragmente prirode ili apstraktne pojmove, odnosno kao serija stvaralačkih činova boga - tvorca“ (Meletinski, 1984: 207). On dalje objašnjava da ceo svet, prirodu i društvo u raznim vidovima oličava ukupnost bogova i duhova, koja njima i upravlja. Pri tom bogovi mogu modelovati istovremeno više elemenata ili samo njihove pojedine aspekte. Ti bogovi su u različitoj meri povezani sa onim što predstavljaju, tako da čak i u okviru iste mitologije, ponekad uporedo, postoje i sam novonastali element, i mitski lik obdaren fantastičnim svojstvima, uključujući tu i povezanost sa konkretnom prirodnom pojavom.

Poslednji i najvažniji u nizu novonastalih muško-ženskih parova je prapredački par koji čine bog i boginja zavođenja, brat i sestra Izanaki i Izanami. Kembel ukazuje na to da ,prvi rezultat kosmogonijskih emanacija jeste postavljanje okvira za prostor; drugi jeste stvaranje života unutar tog okvira: života polarizovanog radi samoreprodukcije na dvojnu formu muškog i ženskog“" (Kembel, 2004: 242).

Poglavlje o bogovima Izanakiju i Izanami obiluje osobito stilizovanim univerzalnim temama i motivima, prepoznatljivim i iz drugih tradicija i mitologija. ${ }^{9}$ Činjenica da su Izanaki i Izanami istovremeno muž i žena,

8 „Vrata“ u imenima označavaju muški i ženski polni organ.

9 I naučnici van Japana uočavaju važnost ovoj japanskog mita. Tako Trevor 
ali i brat i sestra, ne govori o nemoralnosti bogova i vladara, već o težnji za sjedinjenjem sa sebi sličnim, što svedoči o prisutnosti primitivne endogamije u japanskoj starini. Običaj incesta, kako to vidi Obajaši Tarjo, predstavlja odraz vladarskog položaja, tako visokog da izvan vladarske porodice nije bilo moguće pronaći adekvatnog supružnika istoga ranga. Uz to, ,svetost roditelja kombinuje se i dalje uvećava incestuoznim ujedinjenjem, tako da je rang prvorođenog deteta još viši od ranga njegovih roditelja“"(Obayashi, 1985: 14-19).

Nebeski bogovi zapovedaju ovom božanskom paru da uobliče i učvrste zemlju koja je još uvek plutala kao masnoća na površini vode. ${ }^{10}$ Oni to čine mešajući morsku vodu nebeskim kopljem optočenim draguljima (ame no nuboko). ${ }^{11}$ Od kapi na vrhu koplja nastaje ostrvo. Predstava o moru kao prvobitnom elementu od kog nastaje zemlja ima univerzalan karakter i može se naći u skoro svim mitologijama sveta. Izanaki i Izanami silaze na novonastalo ostrvo, podižu nebeski stub i grade palatu. Podizanje palate najavljuje nastavak događaja u mitu jer bez doma u kome će par živeti, nema bračnog života. Da bi se rađanje ozvaničilo, i na određeni način ozakonilo, par se mora venčati, što govori o uređenim društvenim, pre svega porodičnim odnosima u drevnoj japanskoj zajednici. Zato pristupaju božanskom venčanju (teogamija), uz ritualno obilaženje oko stuba. To je ujedno jedini primer svadbene ceremonije u Kođikiju. Obilaženje oko stuba predstavlja običaj sačuvan iz drevnih vremena, koji je ujedno i obred molitve za bogati rod, rasprostranjen u predelima gde se gaji pirinač.

Nebeski stub, kao i koplje kojim Izanaki i Izanami stvaraju prvo kopno, simbolizuje vertikalnu osu sveta, axis mundi, koja spaja nebo i zemlju.

Ling (2003: 137), pionir iz oblasti proučavanja religije u Velikoj Britaniji, koji se bavi i budizmom, objašnjava kako je za drevne Japance stvaranje sveta bio „ishod polnog sjedinjenja dvoje samonastalih supružnika: muškog, zvanog Izanagi, i ženskog, poznatog kao Izanami.“

10 „Kosmogonijskom shvatanju o prvobitnosti okeana odgovara kosmološki model kopna okruženog svetskim okeanom. Predstava o vodenom haosu nalazi se i u osnovi široko rasprostranjenog motiva svetskog poptopa, koji se navodno dogodio u prvobitno vreme." (Meletinski 1984: 210) Sa različitim varijacijama, prikaz velikog potopa deo je mitologije i legendi gotovo svake tradicije u svetu. I u japanskoj mitologiji pronalazimo odjeke ovih verovanja. Kođiki piše da se zbog Susanoovog plača, sva voda u prirodi pretvorila u njegove suze što je izazvalo niz drugih negativnih pojava.

11 Reč je, zapravo, o bronzanom koplju širokog sečiva - prvobitno oružju donetom iz Kine, koje je u Japanu do III veka poprimilo obredni karakter. 
Stub je takođe i pojam stamenitosti, garantuje stabilnost i uređenost sveta. Stoji između muškarca i žene, vezujući ih i ujedinjujući. Ujedno je falusni simbol, koji predstavlja muški princip, plodnost i životodavnu silu. Srodno stubu je „drvo sveta“, središnja figura vertikalnog kosmičkog modela, koja se javlja kao rezultat binarne opozicije gore-dole (up. Meletinski, 1984: 217-218).

Tokom obreda venčanja, žena je prekršila tabu. Progovorila je prva i zbog toga je bračni par kažnjen rođenjem prvog deteta koje je ličilo na pijavicu. ${ }^{12}$ Deformisano dete ne može imati ulogu u kosmogonijskom procesu već mora biti odbačeno, pa Izanaki i Izanami dete stavljaju u čamac od trske i puštaju niz vodu. Ovaj čin je odraz običaja sahranjivanja u vodi, praktikovanog u drevnom Japanu, ali ujedno predstavlja i poznati internacionalni motiv. Dete bačeno u more jedna je od najznačajnijih mitoloških tema vezanih za simboliku vode. Greška je ispravljena tek kada su Izanaki i Izanami ponovili obred venčanja i kada je muškarac dobio prvenstvo. Tako postaje moguć božanski brak (hieros gamos), i ujedno i nastavak teogonijskih (kosmogonijskih i etioloških) procesa.

Japanski mit o stvaranju zemlje i bogova daje pregled četrnaest ostrva i trideset pet bogova, nastalih polnim sjedinjenjem božanskog praroditeljskog para. Novostvoreni bogovi personifikuju različite elemente prirode. Razmatrajući japansku mitologiju, Meletinski piše da ona pripada razvijenim mitologijama, u kojima je proces kosmogeneze predstavljen kao „teogonijska genealogija, u kojoj jedni bogovi, koji modeluju izvesne prirodne predmete, rađaju, ponekad na ne sasvim normalan način (znak natprirodnog), druge bogove, koji modeluju određene fragmente prirode ili, čak, apstraktne pojmove“ (Meletinski, 1984: 207).

Nadalje se teogonijski procesi u japanskom zapisu ostvaruju uglavnom različitim vrstama metamorfoza. Rodivši poslednjeg u nizu, boga vatre, Izanami se teško razboli i umre, čime se boginji dodeljuju i osobine smrtnika. (Kosmogonijsko značenje vatre je ambivalentno i na granici je između prirode i kulture.) I bog Izanaki pokazuje emocije karakteristične za čoveka u afektu: ubija novorođenog sina kriveći ga za ženinu smrt. Kođiki otkriva karakteristike jedne vrste mitova o stvaranju,

12 Meletinski naglašava da je mitsko (početno, prvo, rano) vreme - epoha „prvih predmeta, prvih radnji: prva vatra, prvo koplje, prva kuća, prvi i stoga paradigmatski činovi fizioloških funkcija, ritualnih radnji, primene lekovitih sredstava,načina lova, prvi moralno negativni ili pozitivni postupci." (Meletinski 2009: 31-32). 
u kojima božanstva nastaju od krvi, izlučevina ili delova tela drugih bogova. Od izlučevina boginje Izanami nastaju bogovi koji oličavaju elemente prirode i ljudske delatnosti u vezi sa zemljom i njenom eksploatacijom. I dok se suze neutešnog Izanakija pretvaraju u boginju plačne planine, krv i telo ubijenog boga vatre transformišu se u različita božanstva. Od krvi nastaje osam bogova, a među njima oni koji personifikuju vodu i sečiva (što ima svoju dodatnu logiku jer se sečivo kuje u vatri). Osim njih, nastaju i bogovi koji oličavaju vatru, grom i munju, budući da u primitivnoj svesti postoji jasna veza između vatre i groma koji vrlo često izaziva vatru. Od delova tela ubijenog boga vatre nastaje osam bogova koji personifikuju delove reljefa.

U potrazi za boginjom Izanami, Izanaki silazi u Zemlju noćne tame. U Kođikiju su razvijene predstave i motivi o podzemnoj zemlji mrtvih, koju od sveta živih odvaja brdo Hira i ogromni kamen koji postavlja Izanaki. Ove prirodne prepreke čine delimično propustljivu magičnu granicu koju može proći samo živi junak, dok je mrtvima to onemogućeno. U ovoj mitološkoj priči prepoznajemo nekoliko dobro poznatih internacionalnih motiva. Pre svega, tu je više motiva kršenja tabua, od kojih jedan, nadaleko poznat kao orfejevski motiv, predstavlja kršenje zabrane gledanja, što za posledicu ima trajnu razdvojenost od voljene osobe. U siže je uklopljen i motiv o Persefoni, po kom kušanje hrane u svetu mrtvih uzrokuje nemogućnost povratka na „ovaj svet“. Možda najpoznatiji internacionalni motiv zastupljen iz ovog segmenta prvog toma japanskog zapisa, predstavlja magični beg. Junak iza sebe baca različite predmete, a njihove transformacije postaju prepreke progoniteljima. Konačno, spajanje funkcija boginje plodnosti i vrhovnog htonskog božanstva, koje prepoznajemo u liku boginje Izanami, takođe je motiv prisutan u kulturama širom sveta.

Pobegavši iz zemlje mrtvih, Izanaki prvo odbacuje predmete koje je nosio sa sobom, a zatim se pročišćava od nečistoće iz podzemnog sveta. $\mathrm{Na}$ taj način nastaje mnoštvo bogova, što znači da se od nečistoće rađa nešto novo, božansko i sveto. Predmeti u Izanakijevom vlasništvu preobražavaju se u bogove koji istovremeno personifikuju elemente prirode (pučina, žal, obala, račvanje puta) i ljudske delatnosti (putovanje, drešenje i merenje). Prvo se transformiše štap, i od njega nastaje mesto koje sprečava ulazak zlih duhova, što granicu između ovog i onog sveta čini čvršćom.

Izanaki potom pribegava obrednom pranju (rečnom i morskom) vodom, nakon kultno nečistog kontakta sa mrtvima. Ovaj čin predstavlja 
početak ideje misogi, ritualnog pročišćenja čistom vodom, što je zapravo prototip jednog od najznačajnijih šintoističkih obreda - obreda pročišćenja, harae (harai). Vodom se sa tela i iz uma uklanjaju nečistoća i greh, i samim tim obavlja duhovno pročišćenje, dok se istovremeno prisvaja nevidljiva snaga vode. Pročišćenje vodom poznato je i u drugim religijama, pa i u hrišćanstvu gde se vodom obavlja sveti čin krštenja. Od nečistoće prvo nastaju bogovi koji personifikuju nesreće, a odmah za njima i oni koji te nesreće i zlo ispravljaju. Ovo je odraz jedne od osobenih crta šinto religije, a to je dualizam, tako da s jedne strane postoje život, zdravlje, čistota i plodnost, a s druge, smrt, bolest, nečistoća i jalovost. Time se u kosmološkom smislu održava ravnoteža koja je preduslov za postojanje i opstanak.

Na samom kraju obrednog pranja, bog Izanaki je isprao levo oko, i tako nastaje Velika boginja sunca, Amaterasu. Boginja Amaterasu je solarno božanstvo i glavni od tri najvažnija dela kosmološke dimenzije postojanja. Sunce je izvor života, stvaranja i razvoja. Bez njegove toplote $\mathrm{i}$ energije ne bi bilo ni života. Japanci su oduvek znali da njihov svet u potpunosti zavisi od primalne moći sunca. Izanaki boginji Amaterasu poverava vlast nad Uzvišenim nebeskim poljem i ovim činom ona postaje vrhovno božanstvo japanskog panteona. Ispiranjem desnog oka nastaje bog meseca Cukujomi, koga Izanaki zadužuje da upravlja Zemljom noći. Zanimljivo je da bogu Meseca u Kođikiju nije pridata posebna važnost i da se on u daljem tekstu više ne spominje. Ispiranjem nosa, nastaje bog oluje i prirodnih sila, Take Haja Susanoo (smatraju ga i božanstvom zvezda), koga postavlja da vlada Morskim poljem. Ova tri božanstva - sunce, mesec i zvezda, predstavljaju trojstvo, u šintoizmu nazivano tri svetla (san hikari), a njihovo postojanje je od fundamentalonog značaja za sve forme života na Zemlji. Uprkos načinu njihovog nastanka, ova tri božanstva smatraju se decom i boginje Izanami i međusobnim srodnicima. „Mit o postanku Meseca i Sunca od očiju nije jedini mit o postanku ovih nebeskih tela u drevnom Japanu, ali je to danas svakako najpoznatiji i reprezentativni motiv“, prisutan svuda po svetu, počev od, Japanu najbliže, kineske mitologije, zatim indijske i drugih (Obayashi, 1986: 9-21).

U Kođikiju sledi mitološka priča o bratu i sestri, bogovima Susanou i Amaterasu. Dok su Velika boginja sunca, Amaterasu i bog Meseca Cukujomi obavljali svoja zaduženja, bog gromovnik Susanoo je plačući neprestano tražio da ide u Zemlju svoje pokojne majke, Izanami. Njegovo ponašanje je izazvalo brojne nesreće. Sva voda u prirodi se pretvori- 
la u njegove suze, tako da su reke i mora sasvim presahnuli, planine se osušile, a zli duhovi preplavili svet i izazvali brojne nesreće. ${ }^{13} \mathrm{Na}$ taj način, Susanoo pokazuje svoj pravi lik trikstera, koji remeti prirodni poredak, izazivajući haos i nesreće, što je sankcionisano njegovim proterivanjem sa Neba. To je sasvim u skladu sa Dilonovim mišljenjem da se u mitu „cene red, verbalna i intelektualna aktivnost, poslušnost, prinuda i lojalnost. Haos, impulsivnost, instinktivno reagovanje, zavist i pobuna uvode nered u harmoniju prvobitne vizije, donoseći sa sobom patnju, razdor i smrt" (Dillon, 2010: 497-498).

Susanoo prvo dolazi do svoje sestre, boginje Amaterasu, da bi se oprostio od nje. Nakon što se uverila u bratovljeve dobre namere, oni se zavetuju i počinju da rađaju decu. Međutim, za razliku od Izanakija i Izanami, oni to ne čine polnim sjedinjenjem već jednim vidom motiva čudesnog začeća - partenogenezom, uz određene magijske radnje. Ovoga puta životvorne osobine imaju njegov mač i njeni dragulji. Incest je morao biti izbegnut, kako se tumači, jer je Amaterasu predačko božanstvo japanskih careva. Zato ona ostaje devica, neokaljana grehom seksualnog čina.

Navodno obradovan rođenjem tri devojčice, a mnogo verovatnije revoltiran time, bog Susanoo divlje slavi pobedu. Pri tom čini razna nevaljalstva i pokreće silne nesreće. Zbog svega toga, Velika boginja sunca, Amaterasu, toliko se uplašila, da se zatvorila u Nebesku pećinu i ostavila svet u potpunom mraku. Zbog toga nebeski bogovi odlučuju da kazne Susanoa. Pošto mu odrede globu, odseku bradu i počupaju nokte sa ruku i nogu, kako bi ga pročistili od počinjenog greha, oni ga izopšte iz nebeskih sfera. Silaskom u središnju sferu, Susanoo gubi osobine trikstera i ponaša se u skladu sa svojstvima kulturnog junaka: ubija čudovišnu zmiju sa osam glava i osam repova, spasavši tako devicu sigurne smrti. ${ }^{14}$ Odatle dospeva u zemlju mrtvih, gde postaje vrhovno htonsko božanstvo umesto svoje majke, boginje Izanami.

13 Osnivač strukturalne antropologije, Klod Levi-Stros, u svojim Mitologikama poredi mit o sinu boga Izanakija, bogu oluje i prirodnih sila, Susanou, sa južnoameričkim mitovima sa motivom deteta koje je majka napustila i koje uporno nastoji da joj se vrati (Levi-Strauss, 1963: 292).

14 Meletinski ukazuje na to da „s neba silaze bogovi ili njihovi naročiti izaslanici, kulturni junaci ili div-junaci koji vrše na zemlji određenu misiju - obučavanja ljudi kulturi, uništavanja zlih demona [...] Na taj način, kosmogonijski čin odvajanja neba od zemlje stvorio je neophodne uslove da se kvalitativno raščlani kosmički prostor u vertikalnom pravcu." (Meletinski 1984: 218) 
Međutim, pre nego što je konačno napustio Uzvišeno nebesko polje, Susanoo u pravom triksterskom duhu, stiže da počini još jedno nedelo. Meletinski pod kosmizacijom haosa podrazumeva i delanje mitskog kulturnog junaka-prapretka, koje se ogleda u nabavljanju kulturnih dobara ili u borbi protiv htoničkih čudovišta. Istovremeno, taj junak je u stanju da unosi i elemente socijalnog haosa (koji je u nizu slučajeva implicira i kosmički haos), ispoljavajući egoizam, gramzivost, hipererotiku, kršeći bračna pravila i zakone. To se delimično objašnjava smeštanjem radnji u mitska vremena, delimično time što se sinkretički junak mita javlja kao glavni subjekat i pozitivnih i negativnih radnji, a delimično i ,time što se elementi haosa predstavljaju kao nekakav odušak, čije dopuštanje, na kraju krajeva, učvršćuje društveni poredak“. (Meletinski, 2009: 38)

Susanoo je od boginje žitarica, Oogecuhime, zatražio hranu za put. Međutim, kada je krišom video da ona iz svog nosa, usta i zadnjice vadi đakonije od kojih priprema raznorazna jela, pomislio je da je ta hrana oskrnavljena, pa ju je zato ubio. Od tela ubijene boginje nastaje sledeće: iz njene glave - svilena buba, iz dva oka - pirinač, iz dva uha - proso, iz nosa - crveni pasulj, iz međunožja - ječam, a iz njene zadnjice - soja. Onda je Majka boginja, Kamu Musuhi, naložila da se zrna sakupe i upotrebe za seme. Ovaj odeljak možemo posmatrati kao etiološku priču o nastanku pet vrsta žitarica i svilene bube od delova tela ubijene boginje. Prvi put $\mathrm{u}$ Kođikiju metamorfoza nije istovremeno u funkciji teogonije, ili, drugim rečima, transformaciojom nastaju konkretni elementi flore $i$ faune, a ne božanstva koja ih oličavaju.

Motiv o nastanku osnovnih poljoprivrednih kultura, u ovom slučaju žitarica, od delova tela raskomadane boginje, rasprostranjen je po azijskom kontinentu, i u literaturi se naziva Hajnuvele (Hainuwele) tip motiva, ili mitema Hajnuvele. ${ }^{15}$ Sličan mit sa širim kontekstom javlja se u kineskoj mitologiji, kada kosmički div Pan Ku (P'an-Ku) umire, a iz delova njegovog tela nastaju svi postojeći elementi sveta. Taj mit razmatra i Meletinski (1984: 205-206), ukazujući na činjenicu da u mitologijama

15 Po istoimenom mitskom liku sa ostrva Seram na ostrvima Maluku, devojci čudesnog rođenja, koja je posedovala mogućnost da vršeći nuždu stvara razne dragocenosti. Kada su je meštani ubili verujući da je grešno to što ona radi, njen muž je raskomadao njeno telo, delove sahranio, a iz svakog od njih nikla je drugačija biljka. Te biljke danas stanovnicima Indonezije predstavljaju osnovnu hranu. Ovaj mit je predstavio A. E. Jansen, posle ekspedicije na ostrva Maluku, a opisao ga je Džozef Kembel u svom radu Maska bogova: Primitivna mitologija (up.: Meletinski 1984: 205-206). 
postoji „kosmička transformacija koja se odnosi na originalni svet bez odgovarajućih ljudskih sredstava za opstanak, koji se kroz neki događaj (npr. smrt Hajnuvele) transformiše u svet poznat ljudskom rodu, u kom je moguće živeti, svet sa vegetacijom, životinjama i drugim što ranije nije postojalo." Mnogi mitovi srodni Hajnuvele tipu i tipu kulturnog heroja poput Prometeja, predstavljaju objašnjenja za događaje koji su transformisali svet u korist čoveka, poput pronalaska zemljoradnje i korišćenje vatre.

Ovaj motiv se može shvatiti i kao odraz običaja prinošenja žrtve radi dobrog roda. Meletinski piše o tome kako se u arhaičnim mitologijama često javljaju priče o stvaranju životinja, biljaka, i drugih prirodnih elemenata od tela ubijenog živog bića, najčešće antropomorfnog lika. Prototip takvog sižea zapravo je žrtvovanje jer se devojka prineta kao žrtva pretvara u žitarice, oživljava biljni svet i sl. Meletinski navodi upravo primer „takozvane miteme Hajnuvele“, svojstvene arhaičnim zemljoradničkim društvima, koja objašnjava shodan ritual (Isto).

Kao što se može zaključiti na osnovu našeg rada, različite varijante mita o stvaranju moguće je pronaći u kulturama naroda širom sveta. Ove predstave imaju i zajedničku karakteristiku: gotovo uvek se kao inicijalna faza procesa stvaranja sveta javlja pretvaranje haosa, kao stanja neuređenosti, u organizovan kosmos. Meletinski (1984: 208-209)ukazuje na to da se entropija savlađuje informacijom, a da je „mitološka informacija par excellence upravo kosmogonija, kao pripovedanje o strukturisanju, formiranju uređenog sveta iz njegovog haotičnog prvobitnog stanja." Takve predstave on pronalazi u polinezijskoj, japanskoj, kineskoj, staroameričkoj (pretkolumbovskoj), egipatskoj, vavilonskoj, grčkoj, skandinavskoj, jevrejskoj i drugim mitologijama. Kada kosmos u mitovima i spolja i iznutra trijumfuje nad haosom, i mitovi na taj način ostvaruju svoju višu namenu. Lauri Honko podseća na ključnu dimenziju mita kao priče o bogovima, religijski prikaz početka sveta, postanje, gde su ,prvobitni događaji primeri božanskih dela kojima su stvoreni svet, priroda i kultura u njihovoj celokupnosti i uspostavljen njihov poredak koji i dalje opstaje“ (Honko, 1984: 41-52). Uprkos tome što se nekada čini da do kosmizacije haosa dolazi spontano, bez uticaja neke „,više sile“, u kosmogonijskim mitovima razvijenih mitoloških sistema preobražavanje haosa u kosmos uglavnom je rezultat regulativne delatnosti bogova.

Kada govorimo o Japanu, upoznavanje sa stranim kulturama, prevashodno sa korejskom i kineskom, podstaklo je zanimanje Japanaca za 
poreklo sveta i sopstvene nacije. Dokaz za to pronalazimo u najstarijim sačuvanim istorijskim hronikama, koje nose elemente herojske idealizacije. U skladu sa namenom, Kođiki pruža samo jednu verziju mita, dok Nihongi daje više varijanti. Osobenost japanske stilizacije ovih predstava, leži u činjenici da se kosmogonija uglavnom poistovećuje sa teogonijom. Drugim rečima, japanski panteon čini zbir personifikovanih prirodnih, geografskih i drugih pojava, na koju ukazuje ime boga-duha. Prvi bogovi japanskog panteona nastaju spontano, da bi stvaranje bilo nastavljeno polnim sjedinjavanjem praroditeljskog para. Nadalje se teogonijski procesi ostvaruju transformacijama najrazličitijih mogućih elemenata u posedu božanstava, među kojima su i izlučevine, krv ili delovi tela. S premeštanjem težišta na središnju sferu, teogonijskih procesa više nema i sve je manje numinoznog. Likovi više nisu bogovi već junaci-ratnici, da bi u trećem tomu dobili isključivo ljudske osobine i postali akteri realnih događaja.

Mi se i danas, poput naših davnih predaka pitamo kada je i na koji način nastao kosmos, da li je on delo jednog tvorca i kakva mu je dalja sudbina. Kada se zamislimo nad tim, shvatamo da u tim razmišljanjima i nismo odmakli mnogo jer je naše viđenje kosmosa i dalje umnogome u sferi nagađanja. 


\section{LITERATURA}

Dillon, J. J. (2010). The Primal Vision: The Psychological Effects of Creation Myth. Journal of Humanistic Psychology (pp. 497-498). [on-line]. Dostupno preko: http://jhp.sagepub.com/content/50/4/495 [27. 03, 2020]

Ellis, H. W. (1982). Creationism Discussion Continues. Physics Today, Vol. 35, No.10, (pp. 12-13).

Frejzer, DŽ. DŽ. (2003). Zlatna grana. Beograd: Ivanišević.

Hasel, G. (1974). The Polemic Nature of the Genesis Cosmology. The Evangelical Quarterly, Vol.46, No.2, April-June, (pp. 81-102).

Honko, L. (1984) The problem of defining myth. In A. Dundes (Ed.), Sacred narrative: readings in the theory of myth. Berkeley: University of California Press, (pp. 41-52).

Kembel, DŽ. (2004). Heroj sa hiljadu lica. Novi Sad: Stylos.

Kođiki - Zapisi o drevnim događajima. Oo no Jasumaro (ed.) Prev. sa starojapanskog jezika Jamasaki-Vukelić H, Vasić D, Kličković D, Glumac D (2008). Beograd: Rad.

Levi-Stros, K. (1982). Mitologike 2: Od meda do pepela. Beograd: Prosveta, BIGZ.

Long, C. Alpha (1963). The Myths of Creation. New York: Collier Books.

Meletinski, E. M. (1984). Poetika mita. Beograd: Nolit.

Meletinski, J. M. (2009). Uvod u istorijsku poetiku epa i romana. Beograd: SKZ.

William, G. A. (ed., transl.) (2005). Nihongi: Chronicles of Japan from the Earliest Times to A.D. 697. Rutland: Vt., C.E. Tuttle Co.

Obayashi, T. (1985). Uji Society and Ie Society from Prehistory to Medieval times. Journal of Japanese Studies. Vol. 11, No. 1 / Winter.

Obayashi, T. (1961). Nihon shinwa no kigen. Tokyo: Kadokawa shoten.

Obayashi, T. (1986). Shinwa no keifu - Nihon shinwa no genryuwo saguru. Tokyo: Seidosha.

Ogihara, A. et al. (ed.). (1973). Kojiki, Jodai kayo. Tokyo: Shogakukan.

Sakamoto, T. (ed.) (2000). Nihon koten bungaku taikei 67, Nihonshoki 1. Tokyo: Iwanami shoten, 1982.

Ševalije Ž. i Gerbran A. (2004). Rečnik simbola, Beograd: Stylos.

Van Over, R. (1980). Sun Songs: Creation Myths from Around the World. New York: New American Library.

Vasić, D. (2008). Sunce i mač - Japanski mitovi u delu Kođiki. Beograd: Rad.

Yoshida, A. (1974). Girisha shinwa to Nihon shinwa, hikaku shinwagaku no kokoromi. Tokyo: Misuzu Shobo.

Yoshida, A. (1996). Nihon no shinwa densetsu. Tokyo: Seidosha. 


\section{Danijela Vasić}

\section{JAPANESE CREATION MYTHS}

\section{Summary}

In almost every tradition of the world we can find creation myths, which are extremely important for the community where they appeared. They consist of narrative elements and poetic images, which represent the fundamental aspects of life in ancient community, religious symbols, social norms and customs that constitute a particular tradition. In Japan, such myths are recorded in the oldest extant records: the Kojiki (The Records of Ancient Matters, 712) and the Nihongi (The Chronicles of Japan, 720). Although similar regarding form and content, these works were written with different aims. The Nihongi was written on the model of Chinese official histories. It emphasizes the Japanese national identity, and the autonomy of Japanese Empire in relation to China and Korea. Likewise, this work demonstrates the local culture resources as it keeps all versions of a myth or a legend. On the other hand, the Kojiki was created in order to express a vision of the mythological origin of the imperial family, so it insists on one official version of a tale which best suits the government. These differences are evident at the very beginning of both works - in the creation myth. The Nihongi provides several versions of the creation myth. The first reveals reflection of Chinese mythology, but the other versions of the creation myth in the Nihongi, as well as the selected one in the Kojiki, depict Shinto elements. The theogony in Japanese tradition is often equated with the cosmogony or the various etiological myths about the origin of different elements of nature. The process of creation continues with an ancestor couple's sexual union, and with different transformations: of the goddess' excretions, blood and body parts of murdered gods, objects owned by a particular deity, during ritual purification, etc.

Key words: Kojiki, Nihongi, Shinto, Japanese mythology, creation myth, kami, theogony, cosmogony 